\title{
China's Savings and Current Account Balance: A Demographic Transition Perspective
}

\author{
Chao Zhu \\ School of Finance, Capital University of Economics and Business, \\ Beijing, China \\ E-mail: zhuchaohezhuchao@126.com,zhuchao@cueb.edu.cn \\ Received July 7, 2011; revised August 13, 2011; accepted August 26, 2011
}

\begin{abstract}
In this paper, we build an overlapping generation model to analyze how China's family planning policy affects the demographic structure and the dependency ratios. We also employ the Cointegration Test and Granger Causality Test to examine the relationship between Chinese population dependency ratios and the national savings rate, as well as the relationship between relative productivity differences and the national current account balance. We find that the family planning policy can be sustainable with respect to these metrics. The current account balance reflects the transfer of savings over time and space. We posit that the demographic structure determines the savings transfer over time, while the relative productivity difference determines the savings transfer across the space. This transfer does not change the total welfare calculated on a national or generational basis. Consequently, focusing on improving the consumption rate to boost the economy without consideration of demographic structure transition warrants further serious discussion. Similarly, too much attention to short-term current account surplus or deficit is not productive.
\end{abstract}

Keywords: Savings Rate, Current Account Balance, Demographic Structure, Family Planning Policy

\section{Introduction}

According to Modigliani Life Cycle Hypothesis [1], people tend to save or dissave at different ages to smooth consumption their entire life spans. Thus, demographic structure should be regarded as an important variable in determining the savings rate. Following this strategy, scholars study the relationship between savings rates and demographic change, analyzing whether savings rates are a function of demographic change and then trying to estimate them. But the empirical findings are not consistent. For example, Modigliani and Cao [2] find an obvious cointegration relationship between the savings rate and the dependency ratio in China. They attribute China's high savings rate mainly to high growth and demographic change. However, Kraay [3] uses China's provincial panel data of household savings from 1978 to 1989 to find that the impact of the dependency ratio on savings was not statistically significant. Horioka and Wan [4] believe the impact of China's dependency ratio on the savings rate is only significant in a quarter of the sample. Zheng [5] divides the dependency ratio into youth dependency ratio and old-age dependency ratio.
The results show that the savings rate negatively correlates with the youth dependency ratio, and positively correlates with the old-age dependency ratio. Li et al. [6] conducts a similar analysis using China's provincial panel data, but the results are quite different. They find that the youth dependency ratio has a very small positive impact on savings, while the impact of old-age dependency ratio on both consumption and savings is not significant.

Actually, due to frequent population mobility and free transfer of social security account between provinces, the country's overall data is far more convincing than the provincial data in terms of the relationship between population and economic variables. Moreover, the provincial data might complicate the analysis.

Another common deficiency of the previous research is that China's external economic imbalance is not taken into account. Chen and Hu [7] make efforts to incorporate China's family planning policy into the Blanchard-Fischer inter-temporal model to relax the constant democratic structure hypothesis. They conclude that the current account surplus is the optimal target of China's external balance and prepares an aging population, but 
no empirical analysis is given in the paper.

In an open economy, savings can be divided into internal savings and external savings. The former refers to domestic savings and the latter is the current account surplus. Thus, if demographic structure is correlated with the savings rate, it might also be an important determinant of external equilibrium. Coale and Hoover [8] proposed the controversial hypothesis that a country's rising fertility rate and falling infant mortality rate will result in heavy youth dependency burden (youth dependency) on young families and young governments (his findings were partly based on the data from the large number of new governments established after World War II). Huge consumption leads to fewer savings. Thus, in order to finance the large-scale consumption and investment needed to recover their economies, they have to rely on foreign capital inflows, namely, foreign capital dependency, in the form of current account deficit. Asia is a typical example.

But results from Goldgerger [9] and Ram [10] do not support this hypothesis. Nearly 40 years later, Higgins and Williamson [11] test the hypothesis again with the Asian panel data. They find that increasing savings rates results from the falling youth dependency ratio over the past 30 years. Thus, external capital dependence in Asia will end and the region will begin to export capital in the form of current account surplus. However, the conclusion differs slightly across countries. For China, the surplus was completely under capital flows control in the sample period. In this case, the conclusion is not applicable.

Then, are the savings rate, investment rate and current account surplus correlated with demographic structure? Do current account surpluses occur in young societies and current account deficits in aging societies? In other words, external savings are preparing for when the future population ages? Is it possible that the current account surplus results from the relatively faster increase in China's productivity rather than demographic change? This paper tries to answer these questions using China's empirical data. For simplicity, and to enhance the explanatory power of our results, we focus on demographic variables. We also decompose the total dependency ratio into the youth dependency ratio and the old-age dependency ratio to investigate whether they might have different impacts on dependent variables. Also, based on traditional Chinese values, people tend to spend more on the youth than on the elderly, other things being equal. Such unique feature of Chinese consumption behavior will be taken into consideration. This is another point on which this paper differs from previous work.

We find that China's family planning policy can be sustainable. Relaxing the policy now or in the next few years might be unable to cope with the arrival of a peak of social maintenance. The demographic structure resulting from the family planning policy determines the savings rate, and is the price paid for China's future demographic structure. From an inter-temporal perspective, the current account balance is just the transfer of savings over time and space. In this sense, China need not be too concerned about the current short-term current account surplus.

\section{Demographic Structure Transition under the Family Planning Policy}

This paper will only consider the age structure of China's population. Modigliani [1] believes the savings rate might be correlated with age structure rather than other structures of population. Another consideration is that, due to natural disasters, political reason and family planning policy, China has experienced dramatic changes in age structure in recent decades.

The dependency ratios are often taken as the substitute indicators of population age structure to measure the social burden of a country. The youth dependency ratio is the number of persons 0 to 14 years per one hundred persons 15 to 64 years. The old-age dependency ratio is the number of persons 65 years and over per one hundred persons 15 to 64 years. The total dependency ratio is the number of persons under age 15 plus persons aged 65 or older per one hundred persons 15 to 64. It is the sum of the youth dependency ratio and the old-age dependency ratio ${ }^{1}$.

Now we present a multi-period overlapping generation model to analyze the impact of China's family planning policy on the demographic structure and consider the sustainability of the policy. We start with some assumptions. 1) We divide the life cycle into five age intervals, respectively, 0 - 14, 15 - 30, 31 - 45, 46 - 64 and 65 years old and over. Among them, No. 1 interval corresponds the numerator of youth dependency ratio; No. 5 interval corresponds the numerator of old-age dependency ratio; whereas the middle three intervals correspond the denominator of the dependency ratio (15 - 64) approximately. We treat it with five equal intervals in order to correspond with the dependency ratio, and more impor-

\footnotetext{
${ }^{1}$ People under the age of 18 generally do not have their own income in China. If the college students are counted, the age will be extended to 22. China's retirement age is 60 for men and 55 for women, assuming the same proportion of men and women, the average retirement age is 57.5 years. It is earlier than the retirement age of 65 in most developed countries. So, if the age of 14 and 64 years are the critical points, we are underestimating China's dependency ratio. However, when we study the relationship between the savings (including external and internal savings) and the population dependency ratio, as long as the data are comparable in the sample period, this difference seems not to change the results significantly.
} 
tantly, to keep consistent when every age interval grows older to the next interval ${ }^{2}$. 2) We set 1982 as the starting year when China began to implement strict family planning policy, assuming two persons in every interval. 3) People tend to give birth when they are 30 years old. So the third interval will be the next generation of the first interval. 4) We define China's family planning policy as: first, one couple may only bear one child; second, if both husband and wife are the only child of their parents, they can have two children. Other policy details in different provinces and cities are ignored here. 5) The "relaxation" of the family planning policy means that even the parents who are not only children themselves still can have more than one child, and we assume they wish to have only two children. Table 1 shows the transition of age structure under family planning policy.

Before the implementation of family planning policy (Period 0), the demographic structure is in stable equilibrium, when the total dependency ratio is 67 .

In period 1, the family planning policy becomes effective. Youth population declines, the total dependency ratio drops to 50 from 67 with the denominator being constant. The population burden begins to relax.

In period 2, the young and old populations do not change. But the youth population decreased in period 1 will reduce the labor force in period 2 correspondingly. Youth dependency ratio, old-age dependency ratio and total dependency ratio (60) were improved, but still lower than the original value 67. Both period 1 and 2 can be seen as demographic dividend periods resulting from the family planning policy.

At the beginning of period 3 (corresponding to 2013 approximately), China will face three options: 1) Keep family planning policy forever; 2) Relax the familyplanning policy from period 3; 3) Keep family planning policy till period 5 , and then relax.

In the first case, the couples who are both only children born in periods 1 and 2 can have two children in periods 3 and 4 . Both young people and old people will keep constant, but the labor force continues to fall. The total dependency ratio will reach a peak value of 100 . The country will suffer significant increasing of the population burden. After entering period 5, children who are born in period 3 and are not only children, so they can have only one child again. Thus, the dependency ratio will repeat the cycle beginning from 1982. The population will decline dramatically and enjoy demographic dividends again.

In the second case, we suppose China begins to relax

\footnotetext{
${ }^{2}$ To be sure, it is still not accurate. The former three intervals are 15 years long, whereas, the fourth one is 18 years long. We have to ignore the slight inaccuracy to correspond the fifth intervals to the old-age
} dependency ratio by doing so. family-planning policy from period 3 or period 4 . All couples can have two children, regardless of whether they themselves are only children or not. We have assumed that a couple wishes to have only two children. Actually, the couples who are born in period 1 are all only children. They already have the right to have two children, even if the policy is not relaxed. In other words, relaxing the family planning policy now would not help to avoid the coming peak. The demographic structure would be similar to that of the first case; the peak of dependency ratio will arrive in the 2040s in either case. From period 5, the demographic structure will be rebalanced, the total dependency ratio will return to the initial value of 67 .

In the third case, the family planning will be kept in period 3 and period 4 , and relaxed in period 5 . This case is not different from the second case, except that the total dependency ratio will return to the initial value of 67 in period 7, rather than in period 5 as in the third case.

Now we look at China's population data to test whether it fits the above analysis. Figure 1 shows 100 years of China's dependency ratio data (1950-2050). The data before 1978 are from the World Bank and United Nations Population Division database. Data from 1978 to 2007 are from the "China Statistical Yearbook" and "China Population Statistics Yearbook". For some missing data, we use the fertility rate and mortality rate data to estimate the arithmetic mean value. The data after 2007 are from the forecast of Zhou [13], under the assumption that China's family planning policy remains unchanged.

China began to implement its strict family planning policy in 1982. As a result, the youth dependency ratio began to decrease, the old-age dependency ratio increased slowly, and the total dependency ratio declined to the bottom in the early 20th century. This period of time (from 1982 to the early 20th century) can be compared to periods 1 and 2, when the total dependency ratio declined from 67 to 50 as Table 1 shows and the demographic dividend occurred. In period 3 (approximately throughout the 2020s), the elderly population will grow and the total dependency ratio will increase to its peak in

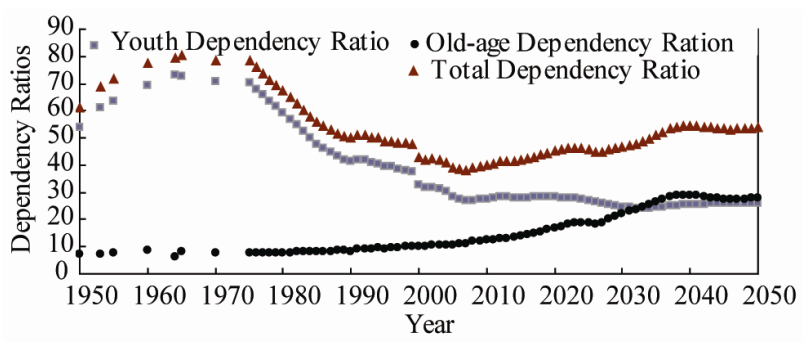

Figure 1. China's dependency ratio (1950-2050). (Sources: NBSC [12] and Zhou [13]). 
Table 1. The transition of age structure under family planning policy.

\begin{tabular}{|c|c|c|c|c|c|c|c|c|c|}
\hline Period/Population & $\begin{array}{c}\text { Persons } \\
0 \text { to } 14 \\
\text { Years } \\
\end{array}$ & $\begin{array}{c}\text { Persons } \\
15 \text { to } 30 \\
\text { Years }\end{array}$ & $\begin{array}{c}\text { Persons } \\
31 \text { to } 45 \\
\text { Years } \\
\end{array}$ & $\begin{array}{c}\text { Persons } \\
45 \text { to } 64 \\
\text { Years }\end{array}$ & $\begin{array}{l}\text { Persons } \\
\text { Aged } 65 \text { or } \\
\text { Older }\end{array}$ & $\begin{array}{c}\text { Total } \\
\text { Population }\end{array}$ & $\begin{array}{c}\text { Youth } \\
\text { Dependency } \\
\text { Ratio }\end{array}$ & $\begin{array}{c}\text { Old-Age } \\
\text { Dependency } \\
\text { Ratio }\end{array}$ & $\begin{array}{c}\text { Total } \\
\text { Dependency } \\
\text { Ratio } \\
\end{array}$ \\
\hline Period 0 & 2 & 2 & 2 & 2 & 2 & 10 & 33 & 33 & 67 \\
\hline \multicolumn{10}{|l|}{ Begin to Implement Family } \\
\hline \multicolumn{10}{|l|}{ Planning Policy } \\
\hline Period 1 (1982-1996) & 1 & 2 & 2 & 2 & 2 & 9 & 17 & 33 & 50 \\
\hline Period 2 (1996-2012) & 1 & 1 & 2 & 2 & 2 & 8 & 20 & 40 & 60 \\
\hline \multicolumn{10}{|c|}{ I. Relax Family Planning Policy } \\
\hline Period 3 (2013-2027) & 1 & 1 & 1 & 2 & 2 & 7 & 25 & 50 & 75 \\
\hline Period 4 (2028-2042) & 1 & 1 & 1 & 1 & 2 & 6 & 33 & 67 & 100 \\
\hline Period 5 (2043-2057) & 0.5 & 1 & 1 & 1 & 1 & 4.5 & 17 & 33 & 50 \\
\hline Period 6 (2058-2072) & 0.5 & 0.5 & 1 & 1 & 1 & 4 & 20 & 40 & 60 \\
\hline Period 7 (2073-2087) & 0.5 & 0.5 & 0.5 & 1 & 1 & 3.5 & 25 & 50 & 75 \\
\hline \multicolumn{10}{|c|}{ II. Relax Family Planning Policy } \\
\hline \multicolumn{10}{|l|}{ From Period 3 or 4} \\
\hline Period 3 (2013-2027) & 1 & 1 & 1 & 2 & 2 & 7 & 25 & 50 & 75 \\
\hline Period 4 (2028-2042) & 1 & 1 & 1 & 1 & 2 & 6 & 33 & 67 & 100 \\
\hline Period 5 (2043-2057) & 1 & 1 & 1 & 1 & 1 & 5 & 33 & 33 & 67 \\
\hline \multicolumn{10}{|c|}{ III. Relax Family Planning Policy } \\
\hline \multicolumn{10}{|l|}{ From Period 5} \\
\hline Period 3 (2013-2027) & 1 & 1 & 1 & 2 & 2 & 2 & 25 & 50 & 75 \\
\hline Period 4 (2028-2042) & 1 & 1 & 1 & 1 & 2 & 2 & 33 & 37 & 100 \\
\hline Period 5 (2043-2057) & 1 & 1 & 1 & 1 & 1 & 1 & 33 & 33 & 67 \\
\hline
\end{tabular}

Sources: the initial data of population (column 1-5) are assumed by the author to simplify the model. Other data are calculated from the initial setting data by the author.

period 4 (around 2040).

In 2043, the beginning of the period 5, the family planning policy faces a critical point for adjustment. If the policy remains unchanged, the total dependency ratio will repeat a cycle of 75-100-50-60-75, just like the previous cycle beginning from 1982. If the policy is relaxed, the total dependency ratio will return to its initial value of 67 and remain stable with a lower total population.

Now, we can discuss family planning policy again. People often have a misunderstanding that the elderly population will bring too much social burden and then doubt the sustainability of China's family planning policy. Actually, this view ignores that the total dependency ratio is composed of not only the old-age dependency ratio but also the youth dependency ratio. To be sure, the family planning policy increases the social pressure of the elderly, but at the same time, it also reduces the pressure of the young. As Table 1 shows, the composite effect will be eventually neutral and stable at the equilibrium value after fluctuating for a period of time.
China's data confirms the above analysis. If the family planning policy remains stable, after some decades, China's population will reach a low total level and an equilibrium low dependency ratio (of course, whether the low total population is our goal might need further discussion). If we want to relax the family planning policy, we will have two critical times for adjustment. The first one is at the beginning of period 3 (approximately 2013). However, as we discussed earlier in this section, relaxing the family planning policy at that time would not help to decline the coming peak around 2040. The second one is at the beginning of period 5 (approximately 2043). If the policy is kept at this point, the population will continue to decline and the dependency ratio will fluctuate just as the cycle beginning from 1982; if the policy is relaxed, the total population and the dependency ratio will remain stable at the level of that time.

In this sense, the family planning policy can be sustainable. For now, relaxation of the policy is unable to cope with the arrival of the peak of social maintenance 
pressure. However, if the policy is kept unchanged, China may enjoy a desirable total population with the same dependency ratio. Thirty years from now (around 2040), what should we do: relax the policy or keep it? It depends on how much population is desirable at that time.

A question may be whether the total population will decrease by $50 \%$ just as estimated in Table $\mathbf{1}$. This researcher believes it depends on the actual effect of the policy. Theoretically, if the policy is carried out as strictly as officially stated, women's total fertility rate would be one. But in fact, China had never reached this level. Total fertility remained at 2 or more during the first 10 years and dropped to 1.34 , where it remained even in 2005. This also explains why the current population did not decrease at the scale estimated in Table $\mathbf{1 .}$ Because of these similar reasons, the actual dependency ratios differ slightly from those in the model, though they share a common rule. The model can provide some ideas for policy, but specific policy decisions should be based on more accurate actual data.

\section{Empirical Results}

\subsection{Variables and Data}

To illustrate the impact of demographic structure on internal and external savings, we take the savings rate (SR), the investment rate (IR), the current account balance (NER) as the dependent variables, assuming all the current account balance are net exports of goods and services. They are all expressed by the percentage of GDP of the same year. We take the total dependency ratio (TDR), youth dependency ratio (YDR) and old-age dependency ratio (ODR) to denote the population structure variables. GDP per capita growth rate represents productivity movement; the relative productivity increase (RPI) represents productivity growth differences between China and the world, denoted by per capita GDP growth rate; CRPI represents the relative productivity increase.

We set 1978 as the starting year and assume that the starting value is zero. Data are from ERS. International Macroeconomic Data Set. Figure 2 shows the movement of China's GDP calculated by expenditure approach for several decades.

The investment rate rose dramatically due to the "Great Leap Forward" began in 1958, and then decline sharply to the bottom because of "Three Years of Natural Disasters” (1959-1962). Another bottom during 1967, 1968, and 1969 is attributed to the beginning of the Cultural Revolution. In 1978, the Chinese economy began to take off. The current account surplus also accelerated.

The data interval is from 1978 to 2007. We give up a

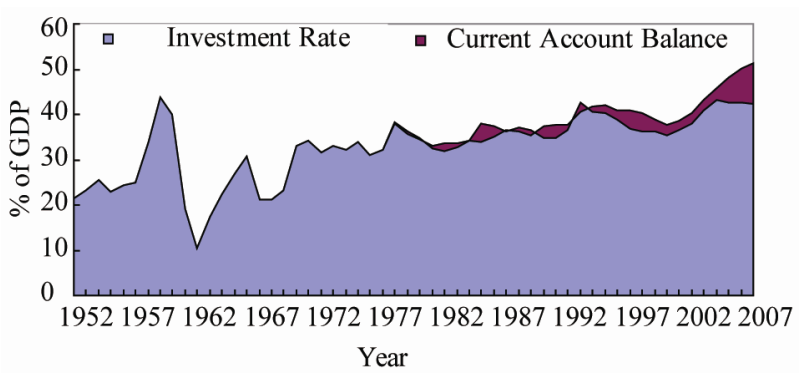

Figure 2. China's GDP and its components (1952-2007). (Sources: NBSC [12]. Notes: Because savings are the sum of investment and net exports, the total area represents the savings rate).

longer data interval mainly because of the following considerations. First, the data before the reform and opening up policy cannot be obtained. Second, some parts of the data-like net exports-are almost zero, which cannot satisfy the data variability. Third, if the data intervals are too long, it might be difficult to reflect the huge institutional changes such as economic policy and family planning policy in the transitional economies.

\subsection{Unit Roots Test}

In this paper, we take ADF to test for stationary of variables to avoid "spurious regression". Table 2 shows the results.

\subsection{Cointegration and Granger Causality Test}

In this paper, we focus on the relationship between two variables. Intuitively, the demographic structure might affect the economic variables like savings rate but the economic variables might have a very weak or even no effect on population. Thus, we prefer the Engle-Granger (EG) two-step cointegration test rather than VAR model. The relative productivity increase (RPI) is a stationary time series and can not participate in a cointegration test here, but the cumulative relative productivity increase (CRPI) is integrated of order one and can be cointegrated. The results are shown in Table 3.

\subsubsection{Savings Rate and Dependency Ratios}

According to the life cycle theory, in the absence of economic growth and new wealth, young people will save for future consumption and dissave as they age. Thus, a young population will be accompanied with high savings rate, while an aging population should be accompanied with a low savings rate. If the dependency ratios are used as a proxy for demographic structure, then, theoretically, the higher total dependency ratio needs more immediate consumption. In other words, the total 
Table 2: ADF test results for unit roots.

\begin{tabular}{|c|c|c|c|c|c|c|c|c|c|}
\hline \multirow[t]{2}{*}{ Variables } & \multicolumn{4}{|c|}{ Level } & \multicolumn{4}{|c|}{ First Differences } & \multirow[b]{2}{*}{ - Results } \\
\hline & $\begin{array}{c}\text { Test Form } \\
(\mathrm{C}, \mathrm{T}, \mathrm{L})\end{array}$ & $\begin{array}{l}\text { ADF- } \\
\text { Statistic }\end{array}$ & $\begin{array}{l}\text { Critical Value at } 1 \% \\
\text { Level of Significance }\end{array}$ & $\begin{array}{l}\text { Critical Value at } 5 \% \\
\text { Level of Significance }\end{array}$ & $\begin{array}{l}\text { Test Form } \\
(\mathrm{C}, \mathrm{T}, \mathrm{L})\end{array}$ & $\begin{array}{l}\text { ADF- } \\
\text { Statistic }\end{array}$ & $\begin{array}{l}\text { Critical Value at } 1 \% \\
\text { Level of Significance }\end{array}$ & $\begin{array}{l}\text { Critical Value at 5\% } \\
\text { Level of Significance }\end{array}$ & \\
\hline SR & $(\mathrm{C}, \mathrm{T}, 6)$ & -3.23 & -4.42 & -3.62 & $(\mathrm{C}, 0,0)$ & -3.25 & -3.69 & -2.97 & $\mathrm{I}(1)^{* *}$ \\
\hline IR & $(\mathrm{C}, 0,2)$ & -2.03 & -3.70 & -2.98 & $(\mathrm{C}, 0,0)$ & -4.13 & -3.69 & -2.97 & $\mathrm{I}(1)^{* * *}$ \\
\hline NER & $(\mathrm{C}, \mathrm{T}, 8)$ & -1.45 & -4.47 & -3.65 & $(\mathrm{C}, 0,1)$ & -4.77 & -3.70 & -2.98 & $\mathrm{I}(1)^{* * *}$ \\
\hline RPI & $(\mathrm{C}, 0,11)$ & -4.36 & -3.85 & -3.04 & $(\mathrm{C}, 0,7)$ & -3.28 & -3.79 & -3.01 & $\mathrm{I}(1)^{* * *}$ \\
\hline CRPI & $(\mathrm{C}, 0,12)$ & -0.42 & -4.62 & -3.71 & $(\mathrm{C}, 0,11)$ & -3.57 & -3.89 & -3.05 & $\mathrm{I}(1)^{* * *}$ \\
\hline TDR & $(\mathrm{C}, \mathrm{T}, 0)$ & -2.50 & -4.31 & -3.57 & $(\mathrm{C}, 0,0)$ & -3.96 & -3.69 & -2.97 & $\mathrm{I}(1)^{* * * *}$ \\
\hline YDR & $(\mathrm{C}, \mathrm{T}, 0)$ & -2.43 & -4.31 & -3.57 & $(\mathrm{C}, 0,0)$ & -3.71 & -3.69 & -2.97 & $\mathrm{I}(1)^{* * *}$ \\
\hline ODR & $(\mathrm{C}, \mathrm{T}, 4)$ & -2.98 & -4.37 & -3.60 & $(\mathrm{C}, 0,0)$ & -6.63 & -3.69 & -2.97 & $\mathrm{I}(1)^{* * * *}$ \\
\hline
\end{tabular}

Sources: the results are calculated by the author using the Eviews 6.0 software. Notes: 1$)^{* * *}$ and ${ }^{* *}$ denotes rejection of the null hypothesis of unit root, at $1 \%$ and 5\% significance levels. We use MacKinnon's [14] critical values for the ADF. 2) (C, T, L) represents the constant term, trend term and the lag, respectively. 3) We chose the AIC criteria and SC criteria for the lag selection. The results show that savings (or its counterpart, consumption) have greater inertia than investment. Exports also show a certain degree of inertia. Compared to the youth dependency ratio, the old-age dependency has greater inertia. That is because, in the absence of war, disasters, large-scale epidemiological situation, the mortality rate is stable while the birth rate tends to be variable.

Table 3. Cointegration test results.

\begin{tabular}{ccccc}
\hline Dependent Variables & Independent Variables & ADF Test (C, T, L) & Residues & Cointegration Equation \\
SR & TDR & $(0,0,13)$ & $\mathrm{I}(0)^{* * *}$ & $(1) \mathrm{SR}=9.4-0.39^{*} \mathrm{TDR}$ \\
SR & YDR & $(0,0,13)$ & $\mathrm{I}(0)^{* * *}$ & $(2) \mathrm{SR}=54.5-0.37^{*} \mathrm{YDR}$ \\
SR & ODR & $(0,0,4)$ & $\mathrm{I}(0)^{* * *}$ & $(3) \mathrm{SR}=2.8+3.94^{*} \mathrm{ODR}$ \\
NER & TDR & $(0,0,0)$ & $\mathrm{I}(0)^{* *}$ & $(4) \mathrm{NER}=11.15-0.19^{*} \mathrm{TDR}$ \\
NER & YDR & $(0,0,0)$ & $\mathrm{I}(0)^{* *}$ & $(5) \mathrm{NER}=8.88-0.17^{*} \mathrm{YDR}$ \\
NER & ODR & $(0,0,1)$ & $\mathrm{I}(0)^{* * *}$ & $(6) \mathrm{NER}=-15.95+1.90^{*} \mathrm{ODR}$ \\
NER & CRPI & $(0,0,1)$ & $\mathrm{I}(0)^{* * *}$ & $(7) \mathrm{NER}=-1.77+0.031^{*} \mathrm{CRPI}$ \\
\hline
\end{tabular}

Sources: the results are calculated by the author using the Eviews 6.0 software. Notes: 1$)^{* * *}$ and ${ }^{* * *}$ denotes $1 \%$ and $5 \%$ significance levels. We use MacKinnon's [14] critical values for the ADF. 2) (C, T, L) represents the constant term, trend term and the lag, respectively. 3) We choose the AIC criteria and SC criteria for the lag selection.

dependency ratio and savings rate are supposed to be negatively correlated. Empirical results show that the savings rate and total dependency ratio are cointegrated. When China's total dependency ratio declines by 1 percentage of GDP, the savings rate will increase by 0.39 percentage of GDP (see Table 3). China's data support the life cycle theory, and the result is consistent with Modigliani [1]. China's steadily rising savings rate in recent years is significantly correlated with the demographic structure movement. The explanation is that China is enjoying a demographic dividend. The total dependency ratio and consumption relative to savings decline, so the savings rate increases.

We then decompose the total dependency ratio to the old-age dependency ratio and the youth dependency ratio for further analysis. Table $\mathbf{3}$ shows that when China's youth dependency ratio decreases by 1 percentage, the savings rate will increase by 0.37 percentage of GDP. After the implementation of family planning policy,
China's birth rate and the proportion of young population have been declining. The center of gravity of the population moves toward young and middle ages, while still not reaching old age, which leads to the decline in the youth dependency ratio and the savings rate. The cointegration equation supports that. China's family planning policy is an important reason for China's declining birth rate and increasing high savings.

The cointegration equation shows that if the old-age dependency ratio increases by one percentage, the savings rate will increase by 3.94 percentage of GDP accordingly. This seems to be inconsistent with the traditional theory. According to the traditional theory, more old people need more consumption, and then the savings rate should decrease consistently. But we think the equation reflects the fact accurately. We have at least three reasons for that.

First, the life cycle hypothesis has a strict assumption that there is no income and legacy after retirement. Re- 
tired people can only spend their previous savings for consumption. But this assumption is not satisfactory. In China, the elderly in rural areas rarely rely on previous savings. On the contrary, their new revenue can often cover the current consumption. Sometimes, they even have new savings. In urban areas, the elderly may even leave some legacy to the next generation, rather than zero, assumed by life cycle hypothesis. So, at least for now, the elderly who are counted in the total dependency ratio in China are not generating complete dependency needs.

Second, due to China's family planning policy, China's current family structure is transforming from a pyramid shape to that of an inverted pyramid. The elderly can no longer rely on their descendants due to the "4-2-1" family structure ${ }^{3}$. They have to prepare excess savings for themselves rather than "bringing up sons to support parents in their old age", as the ancient Chinese idiom goes. Thus, in the short run (such as the transition period lasting for 1 - 2 generations), the increase in the elderly population will make the savings rate increase, not decrease. But in the long run, if the family planning policy continues, the elderly will gradually decrease to the normal and stable level. The excess savings will diminish slowly. If the family planning policy is relaxed, then young population will grow. The excessive savings effect will soon disappear, because the old people can rely on "bringing up sons to support parents in their old age" again.

Third, the values contained in another Chinese idiom, "long to see one's child become a dragon when he/she grows up" ${ }^{4}$ have a unique impact. Under the influence of this traditional culture, children often spend more than the elderly. Therefore, although the old-age dependency ratio increases, the increase of consumption due to the positive impact of the old-age dependency ratio might be less than the decrease of consumption due to the falling the youth dependency ratio. The savings rate is more sensitive to the youth dependency ratio than to the old-age dependency ratio.

Therefore, an important explanation for the increase of China's savings rate in recent years is the decline in the total dependency ratio. Among them, the decreased youth dependency ratio dramatically increases the savings rate. The impact of the old-age dependency ratio on the savings rate is opposite to that of the youth dependency ratio. However, the impact of the latter is larger than the former. So taking them both into consideration, the decrease in the total dependency ratio can explain the

\footnotetext{
3 “4” refers to two sets of grandparents, "2" refers to two parents, " 1 " refers to one child.

4"Wang Zi Cheng Long”. "Dragon” in Chinese often implies a very successful person.
}

increase in the savings rate.

\subsubsection{Domestic Savings vs. External Savings}

Savings means future consumption and can be divided into investment and net exports. Investment (labeled as internal savings) can be regarded as the purchase of goods to produce more future products. The current account surplus (labeled as external savings) can be interpreted as exporting savings to foreign countries and then obtaining the claim for future capital and/or goods of them in the form of foreign exchange or other securities.

Demographic dividend can explain why China has a high savings rate, but cannot explain why the savings rate is greater (or less) than investment rate, and subsequently, the current account balance. We initially thought that demographic structure could explain the current account surplus just as Chen and Hu [7] concluded. Unfortunately, we fail to find empirical evidence in this paper to support that conclusion. Considering that the Granger causality test is sensitive to the lag order, we exhaust all the lag orders of 1 - 9 to do the test. The result is completely consistent. For all the lag orders, the demographic structure does not Granger cause current account surplus, and similarly, current account surplus does not Granger cause the demographic structure, although the latter is obvious.

It should be noted that the excessive savings flowing out to other countries in the form of current account surplus will return to China together with its earnings from abroad eventually in the form of a current account deficit. Later generations will still benefit from the previous excess savings. On the contrary, if a country's domestic savings are insufficient to support high investment, foreign capital will flow in to fill the gap in the form of the country's current account deficit. But the foreign capital (or future product) will flow from the host country back to the investors in the form of the country's future current account surplus. In this sense, the United States is just the temporary place for excess savings of creditor countries. U.S. residents can only enjoy the goods produced by their own savings shares. Therefore, from the perspective of transfers across generations, the current excessive consumption the U.S enjoys now must be at the cost of insufficient consumption of the next generation. The current account balance is just the transfer of excess savings over time and space. A country's savings will transfer between different generations and different countries. In terms of space, this kind of transfer does not change the total welfare of a country; in terms of time, it does not change the total welfare of different generations either.

\subsubsection{The Relative Productivity Difference and the Current Account Balance}

Then, what can explain China's current account surplus? 
Let us look at the problem from a different perspective. Is it possible that the current account surplus is only a passive outcome rather than a provocative choice under the competitive market? High savings rate makes current account surplus possible. Intuitively, given high savings rate, the current account surplus may be interpreted by three reasons. First, savings cannot be transformed into investment, due to depressed domestic financial system. We set aside this complicated issue in this paper. The second is the exchange rate regime and level. Wang [15] has shown that the RMB exchange rate and trade balance are not significantly correlated. This paper will not focus on this view either. The third is that China's higher productivity increase relative to the world results in savings spillover (exports). This paper will test the explanatory power of the third reason.

Cumulative productivity increases over years, rather than differences of productivity in a certain year, determines market competitiveness. Therefore, we use the cumulative stock of RPI (CRPI) as the independent variable of the current account balance. Two variables are first-order stationary sequences and can be tested using E-G cointegration. Results show they are cointegrated. The cointegration Equation (7) (see Table 3) shows that when CRPI increases by one percentage point, the current account surplus increases by 0.03 percentage of GDP.

The Granger causality test shows the cumulative difference of relative productivity Granger causes the current account surplus for the lag orders of 1, 2, 3, 4, 5, 6, and 7 at $5 \%$ or $10 \%$ significance. But for the lag orders of 8 and 9, it is not statistically significant. Overall, it can be said that relative productivity statistically Granger causes the current account surplus. However, the current account surplus does not cause the relative productivity. Intuitively, the former might not be the determinant of the latter. Our Granger test confirms this.

Let us now summarize the determination of the current account balance. In period 1, savings are dependent on the current and future demographic structure as discussed above. Among the savings, how much of savings is allocated to external savings (current account surplus) is dependent on the relative productivity in period 1. Relatively higher productivity yields stronger market competitiveness, which then allows for more savings spillover (exports). In period 2, the savings in period 1 are consumed. The current account surplus should flow back to meet the need of expected consumption. At the same time, among the savings in period 2, how much savings is allocated to external savings (current account surplus) is again dependent on the relative productivity in period 2. We may conclude that the relative productivity determines the "spillover" of current account surplus, while the demographic structure determines the "return" of the current account deficit.

\section{Forecast}

In this section, we try to forecast the future demographic structure, savings rate and current account balance. However, two points need to be emphasized. First, all forecasts are model-based. We assume the above cointegration relationship does exist and reflects the underlying rule. If the current equation itself is false, the result might be misleading. Second, all forecasts rely on the principle of Ceteris Paribus, that is, we do not take other factors outside of cointegration equation into account.

We still use the total dependency ratio data from 2008 to 2050 in Zhou [13] to forecast the savings rate using cointegration Equation (1) and the current account surplus using cointegration Equation (7). To reduce the errors, we use the arithmetic average value of every 10 years rather than every single year.

According to the forecast, the total dependency ratio will steadily increase for the next 40 years. As mentioned earlier in Section 3, this would reduce the savings. The savings rate will decrease slowly to $38 \%$, returning to the level of the late 1980s. If the long-run rule exists, we are currently saving for the future consumption. Higher consumption in young populations implies less consumption in older populations. Consequently, we should review the policy of raising the consumption rate to boost economy. Perhaps it may not have the desired effect, and might be at the cost of future social maintenance insolvency.

The current account surplus will be smaller, decreasing from the current $9 \%$ to $1 \%$. There is a discernible trend that the savings are returning to China. Three explanations may help to explain that. First, China has begun to use current savings for the arrival of the peak dependency ratio. Second, the savings rate will decline due

Table 4. Forecast results.

\begin{tabular}{ccccc}
\hline Year/Item & $\begin{array}{c}\text { Average in } \\
\text { 2011-2020 }\end{array}$ & 2021-2030 & 2031-2040 & 2041-2050 \\
\hline $\begin{array}{c}\text { Total } \\
\text { Dependency } \\
\quad \text { Ratio }\end{array}$ & 42.5 & 45.8 & 51.3 & 53.6 \\
$\begin{array}{c}\text { Savings Rate } \\
\text { Current }\end{array}$ & 42.8 & 41.5 & 39.4 & 38.5 \\
$\quad$ Account & 3.1 & 2.4 & 1.4 & 0.96 \\
Balance (\% of GDP) & & & & \\
\hline
\end{tabular}

Sources: NBSC [12], Zhou [13] and the author's calculation using the cointegration equations in Table 3. 
to the higher dependency ratios, which also leads to less capital outflow. Third, China's productivity increase relative to the rest of the world will become smaller. We think the above trends are fairly certain. In this sense, we need not be too concerned about the current short-term current account surplus. In the long run, we can still obtain external balance.

\section{Conclusions and Policy Implications}

In this paper, we build an overlapping generation model to analyze how the family planning policy affects demographic structure and the dependency ratios. We also employ the Cointegration and Granger Causality Tests to explore the relation between population dependency ratios and the savings rate as well as the relationship between relative productivity differences and the current account balance. The main findings are summarized as follows.

First, the existing family planning policy can be sustainable. Under the family planning policy, the dependency ratios will decline to the bottom line in parallel with the demographic dividend, and then increase to a peak. After a period of difficulty, the dependency ratio will rebalance to a low level together with a low total population. From the perspective of dependency ratios, relaxing the policy now or in the next few years may be unable to cope with the arrival of the peak of social maintenance. Meanwhile, an unchanged policy would be helpful to obtain a desired total population. Whether China should relax the policy in the 2040s depends on the level of population desired at that time.

Second, the demographic structure represented by the dependency ratios determines the savings rate. An important explanation for China's high savings rate in recent years is the decline of the total dependency ratio and subsequent demographic dividend resulting from the family planning policy. The impact of the old-age dependency ratio on the savings rate is opposite to that of the youth dependency ratio. However, the impact of the latter is larger than the former. From a policy perspective, if current savings are needed for future consumption, raising consumption to boost China's economy is questionable. The high savings rate now is the price paid for China's future demographic structure.

Third, from an inter-temporal perspective, the current account balance is just the transfer of savings over time and space. Demographic structure determines savings transfers over time, while the relative productivity difference determines savings transfers across space. Both kinds of transfer do not change the total welfare calculated on a national or generational basis. Specifically speaking, the relative productivity determines the "spill- over" of current account surplus, while the demographic structure determines the "return" of the current account deficit. In the long run, China will use current savings for the arrival of the peak dependency ratio. Also, China's productivity increases relative to the rest of the world will become smaller. In this sense, we need not be too concerned about the current short-term current account surplus.

\section{References}

[1] F. Modigliani, "The Life Cycle Hypothesis of Saving and Intercountry Differences in the Saving Ratio,” In: W. A. Elits, M. F. Scott and J. N. Wolfe, Eds., Induction, Growth and Trade, Essays in Honor of Sir Roy Harrod, Oxford, 1970.

[2] F. Modigliani and S. L. Cao, "The Chinese Saving Puzzle and the Life-Cycle Hypothesis," Journal of Economic Literature, Vol. 42, No. 1, 2004, pp. 145-170. doi:10.1257/002205104773558074

[3] A. Kraay, "Household Saving in China," World Bank Economic Review, Vol. 14, No. 3, 2000, pp. 545-570.

[4] C. Y. Horioka and J. Wan, "The Determinants of Household Saving in China: A Dynamic Panel Analysis of Provincial Data,” NBER Working Papers No. 12723, 2006.

[5] C. D. Zheng, “An Empirical Study of the Relationship between Population Structure and Savings Ratio in Different Regions,” Population \& Economy, Vol. 14, No. 6, 2007, pp. 1-5.

[6] W. X. Li, C. S. Xu and C. R. Ai, "The Impacts of Population Age Structure on Household Consumption in China: 1989-2004,” Economic Research Journal, Vol. 54, No. 4, 2008, pp. 118-129.

[7] Z. J. Chen and C. T. Hu, "How Large Should China's Current Account Target Be? A Demographic Structure Perspective,” Modern Economic Science, Vol. 31, No. 4, 2009, pp. 1-11.

[8] A. Coale and E. Hoover, "Population Growth and Economic Development in Low-Income Countries,” Princeton University Press, Princeton, 1958.

[9] A. Goldberger, "Dependency Rates and Savings Rates: Further Comment,” American Economic Review, Vol. 63, No. 1, 1973, pp. 232-33.

[10] R. Ram, "Dependency Rates and Aggregate Savings: A New International Cross-Section Study," American Economic Review, Vol. 72, No. 3, 1982, pp. 537-544.

[11] M. Higgins and G. W. Jeffrey, “Asian Demography and Foreign Capital Dependence,” NBER Working Papers No. 5560, 1996.

[12] NBSC (National Bureau of Statistics of China), "China Statistical Yearbook,” China Statistics Press, Beijing, 1980-2008,.

[13] W. B. Zhou, "The Forecast and Reasearch on the Dependent Ratio For the Next Five Decades,” Statistical Research, Vol. 21, No. 11, 2004, pp. 35-38. 
[14] J. G. MacKinnon, "Numerical Distribution Functions for Unit Root and Cointegration Tests," Journal of Applied Econometrics, Vol. 11, No. 6, 1996, pp. 601-618. doi:10.1002/(SICI)1099-1255(199611)11:6<601::AID-JA

\section{E417>3.0.CO;2-T}

[15] R. Y. Wang, “The Demographic, Trade Balance, and Exchange Rate Policy Adjustment in China,” The Journal of World Economy, Vol. 26, No. 9, 2003, pp. 3-9. 